\title{
Aplikasi Bioflok yang dikombinasikan dengan Probiotik untuk Pencegahan Infeksi Vibrio parahaemolyticus pada Pemelihaaran Udang Vaname (Litopenaeus vannamei)
}

\section{Application of Bioflocs Combined with Probiotics for Prevention of Vibrio Parahaemolyticus Infection In White Shrimp (Litopenaeus vannamei)}

\author{
Fariq Azhar $^{1}$ \\ ${ }^{1}$ Laboratorium Budidaya Perairan \\ Program Studi Budidaya Perairan, Universitas Mataram \\ Jl. Pendidikan 37 Mataram Telp.0370 621435 \\ Email: fariqazhar@unram.ac.id
}

\begin{abstract}
Abstrak
Budidaya udang yang dilakukan dengan sistem intensif ternyata banyak menimbulkan permasalahan. Adanya masalah penyakit di udang yang disebabkan oleh bakteri, virus, ataupun koinfeksi merupakan masalah yang harus ditangani. Penggunaan probitik dan bioflok merupakan salah satu cara untuk mengatasi penyakit yang ada. Selain itu, kombinasi tersebut diharapkan mampu meningkatkan performa sistem imun udang. Penelitian ini bertujuan untuk mengevaluasi penggunaan bioflok yang dikombinasikan dengan probiotik terhadap sistem imun udang vaname (Litopenaeus vannamei) yang di uji tantang dengan V. parahaemolyticus. Penelitian ini dilakukan selama 5 bulan. Perlakuan yang diberikan yaitu penambahan probiotik komersil dalam media budidaya dengan sistem bioflok pada pakan berupa kontrol negatif (tanpa probiotik + tanpa bioflok) (1), kontrol positif (media budidaya bioflok dan tanpa penambahan probiotik) (2), probiotik I + bioflok (3), probiotik II + bioflok (4), dan probiotik III + bioflok (5).. Hasil yang diperoleh untuk performa performa sistem imun udang terbaik pada perlakuan 4 (probiotik II + bioflok) dengan hasil SR sebesar 76,67\%, THC sebesar $9,7 \times 10^{6} \mathrm{ml}^{-1}$, dan total jumlah bakteri sebesar $1.59 \times 10^{7}$.
\end{abstract}

Kata kunci: Udang vaname, Probiotik, Bioflok, Sistem Imun.

\begin{abstract}
Shrimp farming with intensive system was causing many problems. The presence of disease problems in shrimp caused by bacteria, viruses, or co-infection was a problem that must be solved. The use of probiotics and biofloc was one way to overcome the existing diseases. In addition, the combination was expected to improve the performance of the shrimp immune system. This study aimed to evaluate the using of biofloc combined with probiotics against vannamei (Litopenaeus vannamei) immune system in the challenge test with $V$. parahaemolyticus. This research was conducted for 5 months. The treatments were the addition of commercial probiotics in the culture medium with biofloc system on the feed in the form of negative control (without probiotics + without biofloc) (1), positive control (biofloc culture medium and without probiotic adduction) (2), probiotics I + bioflok (3), probiotics II + biofloc (4), and probiotics III + bioflok (5). The results obtained for the performance performance of the shrimp immune system that the best in treatment 4 (probiotic II + biofloc) with SR yield of $76.67 \%$, THC of $9.7 \times 10^{6} \mathrm{ml}^{-1}$, and total bacterial count of $1.59 \times 10^{7}$.
\end{abstract}

Keywords: Vannamei, Probiotics, Biofloc, Immune System. 


\section{PENDAHULUAN}

Budidaya udang dengan sistem intensif ternyata banyak menimbulkan permasalahan. Adanya masalah penyakit di udang yang disebabkan oleh bakteri, virus, ataupun koinfeksi merupakan masalah yang harus ditangani (Teixeira-Lopes 2011). Vibrio parahaemolyticus merupakan bakteri gram negatif yang banyak ditemukan di air laut. $V$. parahaemolyticus merupakan bakteri yang menyebabkan penyakit Acute Hepatopancreatic Necrosis Disease (AHPND) atau sering dikenal dengan nama Early Mortality Syndrome (EMS). Penyakit EMS menyerang stadia post larva dan dapat menyebabkan kematian hingga $100 \%$ dalam 20-30 hari setelah dilakukan penebaran (De Schryver et al., 2014; Flegel 2012). Selain itu, penyakit EMS juga dapat menyerang stadia akhir dari juvenile udang (Raja 2017).

Penelitian tentang penyakit EMS yang disebakan oleh $V$. parahaemolyticus telah banyak dilakukan. Hasil yang diperoleh berupa identifikasi, isolasi, prevalensi keragaman bakteri di tempat yang berbeda dan cara pencegahannya

(Lomelí-Ortega 2014).

Penanggulangan penyakit EMS dapat dikontrol dengan beberapa disinfektan dan antibiotk yang diperbolehkan. Pemberian antibiotik secara terus menerus dapat menyebakan resistensi bakteri dan efek samping lain berupa residu yang dapat membahayakan manusia dan lingkungan (Labreuche, 2012).

Teknologi bioflok merupakan alternatif yang dapat dilakukan untuk mengatasi limbah budidaya. Selain itu dapat memberikan keuntungan lebih dengan menyedaiakan pakan tambahan bagi udang sehingga dapat meningkatkan pertumbuhan dan efisiensi pakan (De Schryver, 2008). Cara lain yang dapat dilakukan juga dengan menambahkan probiotik pada udang yang dibudidaya sehingga mampu meningkatkan sistem imun (Watson et al., 2008).

Probiotik merupakan mikroba tambahan yang memberikan pengaruh menguntungkan bagi inangnya melalui peningkatan nilai nutrisi pakan dan memperbaiki respon inang terhadap penyakit serta 
meningkatkan kualitas lingkungan (Verschuere et al., 2000). Konsep probiotik diterapkan untuk memelihara dan menjaga kesehatan secara preventif melalui perbaikan keseimbangan mikroflora usus. Probiotik menekan pertumbuhan dan perkembangan mikroorganisme patogen di dalam usus. Penelitian tentang probiotik telah banyak dilakukan untuk peningkatan produksi akuakultur sebagai suplemen makanan, peningkatan resistensi terhadap penyakit, serta peningkatan kinerja pertumbuhan (Nayak, 2010). Selain itu, pemberian probiotik dalam kadar yang optimal juga mampu merangsang pertumbuhan dan perkembangan mikroorganisme sejenis yang menguntungkan (Aly et al., 2008). Lactobacillus plantarum juga mampu berasosiasi dengan flora normal, meningkatkan pertumbuhan, meningkatkan efisiensi pakan, dan sistem imun dari lobster air tawar (Qin et al. 2018).

Penelitian ini bertujuan untuk mengevaluasi penggunaan bioflok yang dikombinasikan dengan probiotik terhadap sistem imun udang vaname (Litopenaeus vannamei) yang di uji tantang dengan menggunakan $V$. parahaemolyticus.

\section{METODE PENELITIAN}

\section{Lokasi dan Waktu Penelitian}

Lokasi penelitian dilaksanakan di laboratorium Budidaya Perairan, sedangkan analisis sampel dilakukan di Laboratorium Bioekologi, Program Studi Budidaya Perairan, Universitas Mataram. Penelitian ini dilaksanakan selama lima bulan.

\section{Persiapan Wadah dan Ikan Uji}

Udang vaname yang digunakan dalam penelitian ini adalah udang vaname berukuran $1.3 \pm 0.12$ g/ekor yang dipelihara dengan padat tebar 10 ekor/wadah. Sebelum diberi perlakuan, udang vaname terlebih dahulu dipelihara selama tujuh hari dalam akuarium untuk proses adaptasi. Wadah yang digunakan dalam penelitian berupa akuarium yang berukuran $40 \times 40 \times$ $40 \mathrm{~cm}$ yang diisi $20 \mathrm{~L}$ air dan dilengkapi dengan aerator, selang dan batu aerasi. Sumber air yang digunakan adalah air sumur, dengan tanpa pergantian air (zero water exchange). 


\section{Persiapan Pakan Uji}

Pakan yang digunakan dalam penelitian ini adalah pakan pellet dengan kadar protein $45.77 \%$. Sebelum diberikan kepada udang, pakan difermentasikan terlebih dahulu dengan bakteri probiotik komersil yang berbeda sebanyak 2 $\mathrm{ml} / \mathrm{kg}$ pakan, dengan dosis $10^{6} \mathrm{CFU}$ $\mathrm{ml}^{-1}$. Pada perlakuan juga ditambahkan karbon berupa molase.

\section{Perlakuan}

Perlakuan yang diberikan yaitu penambahan probiotik komersil dalam media budidaya dengan sistem bioflok dan pakan pellet hasil fermentasi dengan berbagai probiotik komersil selama 30 hari, yakni kontrol negatif (tanpa probiotik + tanpa bioflok) (1), kontrol positif (media budidaya bioflok dan tanpa penambahan probiotik) (2), probiotik I + bioflok (3), probiotik II + bioflok (4), dan probiotik III + bioflok (5). Selanjutnya dilakukan uji tantang dengan menggunakan $V$. parahaemolyticus $\left(10^{6} \mathrm{CFU} / \mathrm{ml}\right)$ (Qin et al. 2018) untuk semua perlakuan kecuali kontrol negative yang diinjeksi dengan PBS.

\section{Parameter yang diamati}

Parameter yang diamati pada perlakuan ini meliputi survival rate (SR), total haemocyte count (THC) (Blaxhall and Daishley 1973), differential haemocyte (DL) (Hsieh et al. 2008), total bacteria count (TBC) dan total Vibrio count (TVC).

\section{Analisa Data}

Analisis data dilakukan dengan menggunakan Univariate Analysis of Variance dengan menggunakan software Statistical Package for Social Sciences/SPSS versi 20.0 for Windows.

\section{HASIL DAN PEMBAHASAN}

Hasil

1. Survival Rate

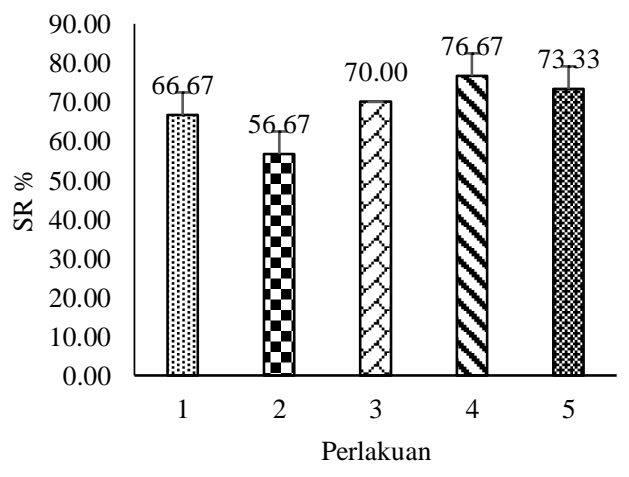

Gambar 1. Sintasan udang uji (Litopenaeus vannamei) setelah uji tantang dengan V. parahaemolyticus.

Nilai SR yang diperoleh setelah dilakukan uji tantang 
Journal of Aquaculture Science

DOI: https://doi.org/10.31093/joas.v3i1.38
April 2018 vol 3 (1): 28-37

Online pada http://joas.co.id tertinggi diperoleh pada perlakuan 4 (probiotik II + bioflok) sebesar $76,67 \%$, diikuti dengan perlakuan 5 (probiotik III + bioflok) sebesar 73,33\%, perlakuan 3 (probiotik I + bioflok) sebesar $70 \%$, perlakuan 1 (kontrol negative) sebesar 66,67\%, perlakuan 2 (kontrol positif) sebesar $56,67 \%$. Hasil yang terlihat menunjukkan adanya perbedaan yang signifikan antara perlakuan dengan kontrol positif.

\section{Total Haemocyte Count}

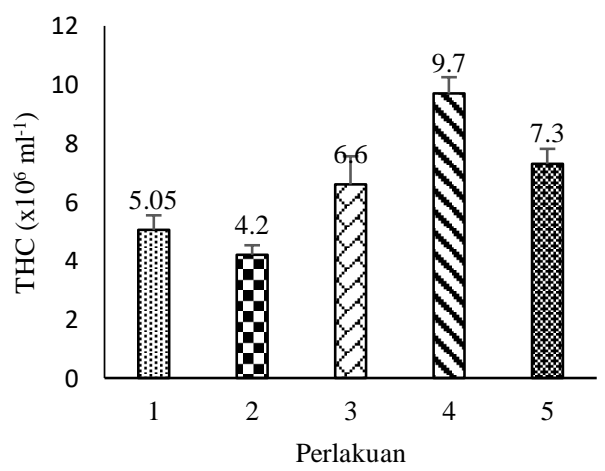

Gambar 2. Nilai THC yang diperoleh setelah dilakukan uji tantang dengan $V$. parahaemolyticus.

Parameter THC yang diperoleh selama percobaan menunjukkan bahwa terjadi perbedaan yang signifikan dari perlakuan terhadap kontrol. Nilai THC tertinggi diperoleh pada perlakuan perlakuan 4 (probiotik II + bioflok) sebesar 9,7 x $10^{6} \mathrm{ml}^{-1}$, diikuti pelakuan ke 5 (probiotik III + bioflok) sebesar 7,3 x
$10^{6} \mathrm{ml}^{-1}$, perlakuan 3 (probiotik I + bioflok) sebesar $6,6 \times 10^{6} \mathrm{ml}^{-1}$, perlakuan 1 (kontrol negative) sebesar $5,05 \quad$ x $10^{6} \quad \mathrm{ml}^{-1}$, dan perlakuan 2 (kontrol positif) sebesar $4,2 \times 10^{6} \mathrm{ml}^{-1}$. Nilai yang diperoleh menunjukkan adanya perbedaan yang signifikan antara perlakuan dengan kontrol positif.

\section{Differential Haemocyte}

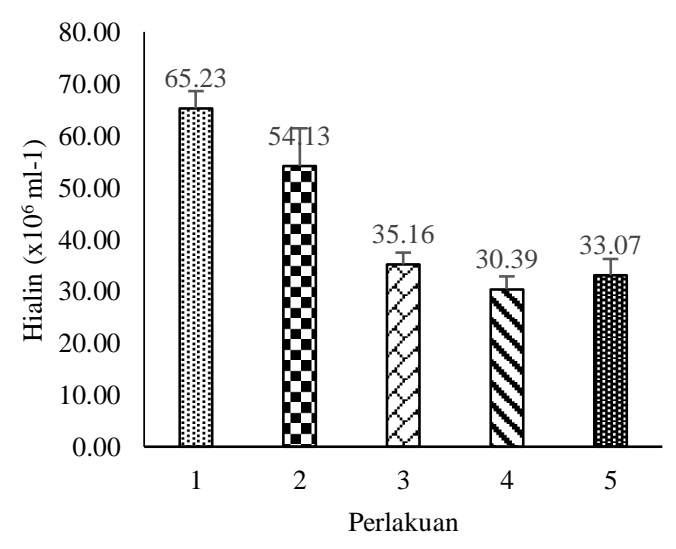

(A)

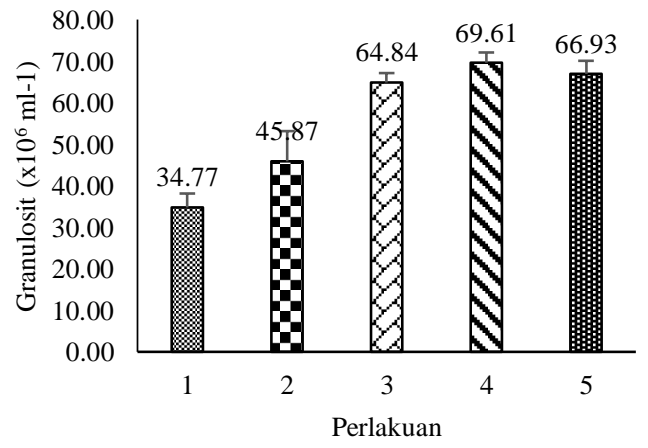

(B)

Gambar 3. Nilai DH udang vaname setelah dilakukan uji tantang dengan $V$. parahaemolyticus. (Litopenaeus vannamei); A (hialin); B (granulosit) 
Nilai DH yang diperoleh selama pengamatan menunjukkan bahwa nilai hialin tertinggi diperoleh perlakuan 1 sebesar $65,23 \times 10^{6} \mathrm{ml}^{-1}$ dan nilai hialin terendah diperoleh perlakuan 4 sebesar $30,39 \times 10^{6} \mathrm{ml}^{-1}$. Sedangkan nilai granulosit tertinggi diperoleh pada perlakuan 4 sebesar $69,61 \times 10^{6} \mathrm{ml}^{-1}$ dan yang terendah pada perlakuan 1 sebesar $34,77 \times 10^{6}$ $\mathrm{ml}^{-1}$. Hasil tersebut menunjukkan

\section{Total Bacteria Count dan Total Vibrio Count}

Total bakteri dan total vibrio yang diperoleh selama penelitian ditampilkan pada Tabel 1. Hasil yang diperoleh menunjukkan adanya peningkatan jumlah bakteri yang ditemukan pada semua perlakuan diakhir penelitian. nilai yang signifikan antara perlakuan dengan kontrol.

Tabel 1. Jumlah total bakteri dan total vibrio (CFU/ml)

\begin{tabular}{lcccc}
\hline Sampel & $\begin{array}{c}\text { Total bakteri } \\
\text { awal }\end{array}$ & $\begin{array}{c}\text { Total bakteri } \\
\text { akhir }\end{array}$ & $\begin{array}{c}\text { Total vibrio } \\
\text { awal }\end{array}$ & $\begin{array}{c}\text { Total vibrio } \\
\text { akhir }\end{array}$ \\
\hline P1 (Kontrol -) & $4.51 \times 10^{3}$ & $2.63 \times 10^{4}$ & $2.12 \times 10^{3}$ & $3.32 \times 10^{3}$ \\
P2 (Kontrol +) & $3.82 \times 10^{3}$ & $2.54 \times 10^{5}$ & $2.45 \times 10^{3}$ & $3.04 \times 10^{4}$ \\
P3 (probiotik I + bioflok) & $5.22 \times 10^{4}$ & $1.64 \times 10^{6}$ & $2.95 \times 10^{3}$ & $9.03 \times 10^{4}$ \\
P4 (probiotik II + bioflok) & $5.39 \times 10^{4}$ & $1.59 \times 10^{7}$ & $5.56 \times 10^{3}$ & $7.17 \times 10^{4}$ \\
P5 (probiotik III + bioflok) & $2.78 \times 10^{4}$ & $1.17 \times 10^{7}$ & $8.35 \times 10^{3}$ & $6.46 \times 10^{4}$
\end{tabular}

\section{Pembahasan}

Bioflok merupakan campuran heterogen dari mikroorganisme, partikel, koloid, polimer organik, kation dan sel mati (De Schryver et al., 2008). Teknologi bioflok merupakan alternatif cara untuk mengelola kualitas air budidaya secara in situ tanpa mempengaruhi produki udang. Manipulasi rasio $\mathrm{C} / \mathrm{N}$ dalam air budidaya dengan penambahan sumber karbon melalui pakan dan sumber ekternal lainnya (molase, gula, ubi, dll) akan merangsang biomassa mikroba yang ada (Avnimelech 1999). Hasil yang ditunjukkan untuk nilai SR yang diperoleh selama percobaan menunjukkan nilai yang signifikan antara perlakuan dengan kontrol setelah dilakukan uji tantang dengan V. parahaemolyticus. Perlakuan 4 
merupakan nilai SR tertinggi dan perlakuan 2 mempunyai hasil yang terendah. Tingginya nilai SR yang diperoleh menunjukkan bahwa bioflok tersebut mempunyai kandungan nutrisi penting dan meningkatkan antioksidan yang ada didalamnya. Meningkatnya respon imun udang tersebut dapat mempengaruhi nilai sintasan menjadi lebih tinggi, karena resistensi udang terhadap patogen juga meningkat. Jadi semua udang yang diberi perlakuan bioflok menunjukkan kondisi yang lebih sehat daripada kolam kontrol. Khatoon et al. (2016), menyatakan bahwa penambahan bioflok 50\% ke pakan memberikan hasil paling baik untuk SR udang.

THC yang diperoleh selama percobaan menunjukkan hasil tertinggi untuk pelakuan 4. Hasil tersebut berbeda nyata dengan semua perlakuan. Pemberian probiotik dan bioflok dalam air budidaya ternyata mampu meningkatkan nilai THC dibandingkan dengan kontrol. Menurut (Hauton, 2012), menyatakan bahwa hemosit memainkan peranan yang sangat penting dalam tubuh crustacea, karena hemosit mampu menghilangkan partikel asing yang terdapat di dalam tubuh udang. Meningkatnya jumlah haemosit dalam tubuh udang akan meminimalkan infeksi $V$. parahaemolyticus dan mampu meningkatkan SR setelah diuji tantang dengan $V$. parahaemolyticus. Jumlah THC pada kontrol yang sedikit menunjukkan adanya efek yang berlangsung selama berjalannya mekanisme pertahanan tubuh terhadap serangan patogen (Smith $e t$ al. 2003).

DH yang diperoleh setelah dilakukan uji tantang dengan $V$. parahaemolyticus menunjukkan adanya peningkatan sel granular dan penurunan sel hialin. Peningkatan jumlah sel hialin berkaitan dengan adanya fagositosis yang ada didalam tubuh udang, sedangkan sel granular mempunyai fungsi untuk memproduksi melanin serta mengeluarkan peptide antimikroba dan terlibat dalam reaksi sitotoksik (Hauton 2012). Selain itu, menurut De Schryver et al. (2008) bioflok mengandung poly- $\beta$-hydroxibutirat (PHB) yang dapat meningkatkan sistem imun. Probiotik Vibrio SKT-b yang ditambahkan dalam sistem 
bioflok juga mempengaruhi tingginya nilai sintasan, karena probiotik SKT-b (Vibrio alginolyticus) efektif menekan pertumbuhan Vibrio harveyi dengan cara kompetisi melalui tempat pelekatan atau sumber nutrisi (Widanarni et al., 2008). Dengan demikian udang yang diberi perlakuan bioflok dan probiotik mempunyai nilai SR yang tinggi dibandingkan dengan kontrol, karena imun sistem yang ada dalam tubuh udang sudah terbentuk dan mampu menghambat pertumbuhan patogen.

Bakteri yang diperoleh pada usus udang pada akhir penelitian menunjukkan peningkatan yang signifikan. Peningkatan tersebut tidak hanya terjadi pada jumlah total bakteri diusus udang tetapi juga jumlah bakteri vibrio. Hal tersebut ditunjukkan pada Tabel 1. Yang menunjukkan bahwa perlakuan yang diberikan yakni pemberian probiotik dan bioflok memiliki jumlah bakteri yang lebih banyak dibandingkan dengan kontrol. Li et al. (2009), melaporkan bahwa peningkatan dosis pemberian probiotik Bacillus dan isomaltooligosakarida (IMO) pada udang vanname menurunkan jumlah total bakteri dan jumlah bakteri Vibrio pada usus udang, namun hal ini meningkatkan imunomudulatory udang tersebut. Meningkatnya performa pertumbuhan udang mungkin disebabkan oleh meningkatkan aktivitas enzim pencernaan yang diinduksi oleh probiotik (Wang, 2007). Menurut Ai et al. (2011), bakteri pencernaan mengambil bagian dalam dekomposisi nutrisi, memberikan makroorganisme dengan bahan aktif secara fisiologis seperti enzim, asam amino dan vitamin, dengan demikian memfasilitasi pemanfaatan pakan dan pencernaan.

\section{Kesimpulan}

Teknologi bioflok dan probiotik dapat meningkatkan performa sistem imun udang terbaik pada perlakuan 4 (probiotik II + bioflok) dengan hasil SR sebesar $76,67 \%$, THC sebesar 9,7 x $10^{6} \mathrm{ml}^{-1}$, dan total jumlah bakteri sebesar 1.59 x $10^{7}$ masing-masing dan $4,9 \%$.

\section{Saran}

Perlu dilakukan penelitian lanjutan tentang sistem imun udang untuk mengetahui efektifitas 
penggunaan bioflok yang

dikombinasikan dengan prebiotik.

\section{UCAPAN TERIMA KASIH}

Penulis mengucapkan terima

kasih kepada Lembaga Penelitian

dan Pengabdian pada Masyarakat

Universitas Mataram.

\section{DAFTAR PUSTAKA}

Ai Q, Xu H, Mai K, Xu W, Wang J, Zhang W. 2011. Effects of dietary supplementation of Bacillus subtilis and fructooligosaccharide on growth performance, survival, non-specific immune response and disease resistance of juvenile large yellow croaker, Larimichthys crocea. Aquaculture, 317: 155-161.

Aly SM, Mohamed MF, John G. 2008. Effect of probiotics on the survival, growth and challenge infection in Tilapia nilotica (Oreochromis niloticus). Aquaculture Research, 39:647-656.

Avnimelech Y. 1999. Carbon/nitrogen ratio as a control element in aquaculture system. Aquaculture, 176: 227-235.

Blaxhall, Daishley KW. 1973. Routine Hematological Methods for Use with Fish Blood. Journal Fish Biology 5: 577-581.

De Schryver P, Carb R, Derfoirth P, Boon N, Verstrete W. 2008. The basics of bio-flocs technology: The added value for aquaculture. Aquaculture, 277: 125-137.

De Schryver P, Derfoirth P, Sorgeloos. 2014. Early mortality syndrome outbreaks: a microbial management issue in shrimp farming. PLOS Pathog., 10(4): e1003919

Flegel, TW. 2012. Historic emergence, impact and current status of shrimp pathogens in Asia, J. Invertebr. Pathol. 110(2) 166-173

Hauton, C. 2012. The scope of the crustacean immune system for disease control. Journal of
Invertebrate Pathology, 110(2), 251260.

Hsieh, S. L., Ruan, Y. H., Li, Y. C., Hsieh, P. S., Hu, C. H., \& Kuo, C. M. (2008). Immune and physiological responses in Pacific white shrimp (Penaeus vannamei) to Vibrio alginolyticus. Aquaculture, 275(1-4), 335-341.

Li, J., Tan, B., \& Mai, K. 2009. Dietary probiotic Bacillus OJ and isomaltooligosaccharides influence the intestine microbial populations, immune responses and resistance to white spot syndrome virus in shrimp (Litopenaeus vannamei). Aquaculture, 291(1-2), 35-40.

Khatoon, H., Banerjee, S., Guan Yuan, G. T., Haris, N., Ikhwanuddin, M., Ambak, M. A., \& Endut, A. 2016. Biofloc as a potential natural feed for shrimp post larvae. International Biodeterioration and Biodegradation, 113, 304-309.

Lomelí-Ortega CO., Sergio F. MartínezDíaz. 2014. Phage therapy against Vibrio parahaemolyticus infection in the whiteleg shrimp (Litopenaeus vannamei) larvae, Aquaculture 434 208-211

Nayak SK. 2010. Probiotics and Immunity: A Fish Perspective. Review. Fish and Shellfish Immunologi, 29: 2-14.

Qin, Z., Babu, V. S., Wan, Q., Zhou, M., Liang, R., Muhammad, A., Lin, L. 2018. Transcriptome analysis of Pacific white shrimp (Litopenaeus vannamei) challenged by Vibrio parahaemolyticus reveals unique immune-related genes. Fish and Shellfish Immunology, 77, 164-174.

Raja R Ananda, R Sridhar, C Balachandran, A Palanisammi, $\mathrm{S}$ Ramesh, $\mathrm{K}$ Nagarajan. 2107. Pathogenicity profile of Vibrio parahaemolyticus in farmed Pacific white shrimp, Penaeus vannamei, Fish. Shellfish Immunol. 67: 368-381.

Smith, V. J., Brown, J. H., \& Hauton, C. 2003. Immunostimulation in crustaceans: Does it really protect against infection? Fish and Shellfish Immunology, 15(1), 71-90.

Teixeira-Lopes MA, Vieira-Girão PRN, da Cruz Freire JE, Rocha ÍRCB, Costa FHF, Rádis-Baptista G. 2011. Natural Co-infection With Infectious Hypodermal and Hematopoietic Necrosis Virus and Infectious 
Myonecrosis Virus in Litopenaeus vannamei in Brazil. Aquaculture, 312: 212-216.

Verschuere L, Rombaut G, Sorgeloos P, Verstraete W. 2000. Probiotic Bacteria as Biological Control Agents in Aquaculture. Microbiology and Molecular Biology Reviews, 64(4): 655-671.

Wang YB. 2007. Effect of Probiotics on Growth Performance and Digestive Enzyme Activity of The Shrimp Penaeus vannamei. Aquaculture, 269: 259-264.

Watson AK, Kaspar H, Lategan MJ, Gibson L. 2008. Probiotics in aquaculture: The need, principles and mechanisms of action and screening processes. Aquaculture, 274: 1-14.

Widanarni, Sukenda, Setiawati M. 2008. Bakteri Probiotik dalam Budidaya Udang: Seleksi, Mekanisme Aksi, Karakterisasi dan Aplikasinya Sebagai Agen Biokontrol. Jurnal Ilmu Pertanian Indonesia, 13 (2): 8089. 